\title{
A Feasibility Study of Site Selection Through GE- Matrix Mapping with Market Attractiveness Parameters and Financial Projection Parameters in Small and Medium Enterprises
}

\author{
M. Iqbal Alamsyah ${ }^{1 *}$ \\ ${ }^{1}$ Sekolah Tinggi Ilmu Ekonomi Indonesia Membangun \\ *Corresponding author.Email: muhammad.iqbal@inaba.ac.id
}

\begin{abstract}
Commencing a new business network is a challenging task because it may have an effect on the company's long-term viability. This is a significant financial investment because, in addition to the market share and growing a company, establishing a business network carries the risk of failure. It also depends on manage-ment's ability to see the potential location, demands, market competitiveness, and business feasibility study performance. Regarding this, a feasibility analysis of site selection is required when deciding between alterna-tive business locations. This study applied a case study with qualitative approach involving GE-Matrix as the tool to make decision. It employed parameters that have been modified by using market attractiveness and fi-nancial projections. Feasibility studies of site selection were conducted on certain location, market potential, territory, competition, risk, and financial projections (BEP, payback period, and profitability index). As a re-search site, this study was done in one of the SMEs in Bandung. The results of the study revealed that the feasibility study by using GE-Matrix gained positive recommendation with a high score and the business loca-tion was eligible to be opened
\end{abstract}

Keywords: Feasibility Study, Financial Projection, Ge-Matrix Mapping, Market Attractiveness, Site Selection.

\section{INTRODUCTION}

Industrial site selection is a critical point in the process of starting, expanding, or changing the location of industrial systems of all kinds. One of the main objectives in industrial site selection is finding the most appropriate site with desired conditions de-fined by the selection criteria [1]. Opening a new branch in business is a critical in-vestment decision for SMEs. Apart from having the opportunity to increase market share and grow a business, opening a new branch also carries a risk of failure [2].

Therefore, this study aims to measure the feasibility of business location for SMEs, which relatively determine data-free decisions. Some scholars have put their attentions on the selection of location of high technology industries. An explanatory study of Mexican and United States electronic firms, reference [3] underlined that high technology location behavior is closely related to the competitive strategy of a firm, the country, and to some extent, the ownership. Although the availability of a skilled and productive workforce is a major factor, firms competition to the differentiation strategy looked for technical and ambiance advantages in a location, while those who compete with a "cost" strategy considered input factors to be more important [4]

It is generally accepted that the characteristics of service and manufacturing companies are distinctly different. The most important discussions are in terms of processing times and usage factors. Traditionally, service businesses have been thought to be geographically connected to markets [5].

Furthermore, reference [6] suggested that the decision of location framework used by managers predominantly emphasizes quantitative analyses that trade-off transport costs, scale economies, and other cost-based variables. Although such a focus may produce short-term cost savings, it may be detrimental to other indicators of productivity such as lead time, inventory, and responsiveness.

In other research, the question of how effective past location decisions are enhancing the competitiveness of global supply chains. This question is of consequence to both practitioners and academics [7].

Any prejudices should discourage scholars from conducting a thorough statistical study. Data bases rapidly become redundant [8]. As a re-sult, researchers 
aim to fill in the holes in their studies by using Business Attractiveness and Financial Projection Factors.

Moreover, the strategic impact of non-economic factors on business site selection is recently being recognized in domestic location decision. For example, in the recent decision for Amazon's second headquarters, the company has listed both economic factors and noneconomic factors such as capital and operating costs, incentives, cultural community fit, and quality of life [9]. Qualitative is-sues such as social and political factors are also influential in many international location decisions [10].

Developing expertise in industrial site selection is a big business as measured by budgets committed, stature of decision-makers involved, size of communities affected, or prosperity of the community influenced. Such optimization often involves numerous decision factors, which are frequently contradicting, and the process often involves a number of possible sites each has advantages and limitations[11].

Investment decisions are made after a complete analysis of the investment project. One of the basic factors that influence decisions is the risk factor of investment. This risk exists because it is uncertain that investment costs will recover and profits will be obtained. [12]. In decision making pro-cesses, people are focused on expected utilities, rather than expected values [13]. Therefore, before business owners make investment decision, they should conduct a feasibility study in their in-vestment.

Regarding the feasibility study, it acts as a tool to make a decision and to accept or reject an invest-ment proposal in building or establishing a project / business plan [14]. One of the objec-tives of the feasibility study is to overcome the risk of loss in the future, because there are uncertain conditions that arise in the future. There are uncertainties that can be predicted will happen or things that are completely unpredictable. In this case, the function of the feasibility study is to minimize un-wanted risks. In addition, the purpose of the feasibility study is to facilitate planning, implementation of work, supervision and control of the project / business undertaken.

This paper presents a decision support system in which GE-Matrix was chosen to be a tool in decision making with parameters that have been modified using market attractiveness parameters and financial projection parameters. Feasibility studies of site se-lection are conducted on location aspects, market potential aspects and territory aspects, competition aspects, risk aspects, and financial projects such as: Breakeven Point (BEP), Payback Period (PP), Net Present Value (NPV), and Profitability Index (PI).

Multi-attribute decision making methods are data oriented. The techniques are referred to as discrete methods because they assume that the number of alternatives is explicit. Multi-attribute decision problems require that choices be made among alternatives described by their attributes. This implies that attribute of objective relationships are specified in such a form that attributes can be regarded as both objectives and decision variables. Attributes are used as both decision variables and decision criteria [1].

\section{METHODS}

This research is a case study in SMEs calculating financial projections and assessing market attractiveness, making assumptions in the business location selection plan. It derives from the notion that planning would be impossible without assumptions. Wild guesses should never be made in formulating strategies, but reasonable assumptions based on available information must always be made [15].

By identifying future occurrences that could have a major effect on the firm and by making reasonable assumptions about those factors, strategists can carry the strategic-management process forward. Assumptions are needed only for future trends and events that are most likely to have a significant effect on the company's business. Based on the best information at the time, assumptions serve as checkpoints on the validity of strategies. If future occurrences deviate significantly from assumptions, strategists know that corrective actions may be needed. Without reasonable assumptions, the strategy-formulation process could not proceed effectively. Firms that have the best information generally make the most accurate assumptions, which can lead to major competitive advantages. [15].

In such way, the total number of available sites, the customer is aware of a certain number of them. Of these, only a certain number of locations meets the selection criteria of the decision maker, so that makes group of sites for consideration.

The presented system benefits decision makers by providing an advisory expert system that recommends the proper values for the desired selection criteria. The parameters component considers the analyst's prioritization of the non-spatial attributes to select the most suitable site among the identified alternatives. The system produces a mapping of alternative locations that can help the owner to make a decision.

Financial condition is also frequently considered as the single-best measure of a firm's competitive position and overall attractiveness to investors. Determining an organization's financial strengths and weaknesses is essential to effectively formulating strategies. A firm's liquidity, leverage, working capital, profitability, asset utilization, cash flow, and equity can eliminate some strategies as being feasible alternatives. Financial factors often alter existing strategies and change implementation plans. [15]. 
Site selection was based almost purely on economical, and technical criteria. As it is recently known that a higher degree of sophistication is expected. Selection criteria should satisfy a number of social and environmental requirements, which are enforced by legislations and government regulations. The selection process of industrial site refers to complex multi-criteria analysis which includes a complex array of factors involving economic, social, technical, environment and political issues that may result in conflicting objectives. [1]. The process begins with the recognition of an existing or projected need. This recognition triggers a series of actions that starts with the identification of location alternatives of interest.

Some of the issues that add to the complexity of the site selection process include existence of: a) a large number of possible sites, b) requirements that could result in contradicting objectives, c) intangible objectives that are difficult to quantify, d) diversity of stakeholders and their priorities, and f) uncertainties regarding future issues that could impact of the validity of today's decisions [11].

The valuation aspect is the financial aspect, location aspect, market and marketing aspect, economic aspects and technical/operational aspects. The valuation aspect used in the business location analysis system employs GE-Matrix on the $\mathrm{X}$ axis is the financial aspect using financial projections while on the $\mathrm{Y}$ axis using the business location aspects and market and marketing aspects. While economic aspects and technical / operational aspects are explained based on calculations in financial projections.

The stages in the process of site selection are data collection, making assumptions and feasibility studies, weighting, determining ratings on each aspect, scoring, mapping using GE-Matrix, and giving recommendations from the mapping results.

The process of site selection includes [1]:

1. Establishing a set of influential factors relevant to site selection,

2. Predicting and evaluating the intensity and direction of their effects in time and given conditions,

3. Evaluation of possible variants of solutions and selection of optimal variant.

The most significant factors that describe decision problems or affect the choice and implementation of MCDA methods the most significant: Number of decision makers, Number of objectives, Number of alternatives, Existence of constraints and Risk tolerance.

\section{Data Collection}

Data collection in this study was taken from various sources information, namely: (1) Interviews conducted with SME owners, local communities, business actors, business location owners, local government parties (2) Focus Group Discussion (FGD) conducted with SME owners, to find out the plan and composition of location investment costs business (3) Field survey (4) Secondary data from the government and business owners.

Collection of information allows the generation of a potential industrial sites that can be grouped, while the use of certain criteria, through several iterations, gradually narrowing to a choice

Making assumptions and feasibility studies

After data collection, assumptions are made in the calculation of financial projections and assess market attractiveness. After that, the data is processed and the location feasibility study is carried out which must cover all aspects of the assessment, namely: market and marketing aspects, business location aspects, financial aspects, technical / operational aspects and economic aspects.

Weighting, determining ratings on each aspect, scoring

Ranking to relative attractiveness $(1=$ most attractive, $2=$ next most attractive, etc.) is a commonly used procedure to help determine which actions to fund.

The process of determining ratings and scores is data processing according to the data that has been collected. whereas the weighting of each indicator based on table 1 .

Table 1 Percentage Variable Factors for X Axis and Y Axis

\begin{tabular}{|l|l|l|l|}
\hline \multicolumn{2}{|c|}{ X Axis } & \multicolumn{2}{c|}{ Y Axis } \\
\hline BEP & $35 \%$ & RA & $30 \%$ \\
\hline PP & $30 \%$ & SA & $15 \%$ \\
\hline NPV & $25 \%$ & MF & $25 \%$ \\
\hline PI & $10 \%$ & SD & $10 \%$ \\
\hline & & CM & $20 \%$ \\
\hline TOTAL & $100 \%$ & TOTAL & $100 \%$ \\
\hline
\end{tabular}

\section{Giving recommendations from the mapping} results

The results of mapping business locations determine alternative strategy suggestions. Furthermore, the advice is submitted to the SME owner for the decision to determine the location of his business.

\section{RESULTS AND DISCUSSION}

In determining site selection, GE-Matrix mapping evaluates location alternatives. GE-Matrix divides mapping positions based on market attractiveness and the 
level of financial projections will be described in several segments and blocks.

Based on the picture above, the combination of the $\mathrm{X}$ axis and $\mathrm{Y}$-axis and finally produce different suggestions, namely: Location feasible to open, suggestions for reallocation, suggestions for relocation and suggestions for locations not opened.

The matrix provides a systematic approach for the multi business corporation to prioritize investments among its location alternatives.

Site selection can be done in accordance with strategic objectives and can increase profits, then the alternative location will be analyzed with market attractiveness parameters and financial projection parameters. The factors calculated in financial projections are: (1) labor costs per month (2) location Costs per month (3) general costs per month (4) Amortization Costs for Monthly Leases (5) Depreciation Costs for Fixed Assets and Inventory Per Month (6) Total Investment Cost (7) Total Monthly Cost (8) Calculation of sales assumptions (9) Profit Margin Calculation (10) Breakeven Point Calculation (11) Calculation of Payback Period (12) NPV and PI calculations, and then (13) Determination of $\mathrm{X}$-axis and $\mathrm{Y}$-axis Rating and Scoring.

The results of the mapping that have been processed can be seen in the following table 2 and fig. 1 .

Table 2. Office Branch Opening Map

\begin{tabular}{|l|l|}
\hline \multicolumn{2}{|c|}{ Location 1 } \\
\hline Address & \multicolumn{2}{|c|}{ Terusan Buah Batu } \\
Axis X & 2,90 \\
Axis Y & 3,80 \\
\hline \multicolumn{2}{|c|}{ Location 2 } \\
\hline \multicolumn{2}{|c|}{ Address } \\
Axis X & 3,90 \\
Axis Y & 3,73 \\
\hline \multicolumn{2}{|c|}{ Location 3 } \\
\hline \multicolumn{2}{|c|}{ Taman Sari } \\
Axis X & 2,30 \\
Axis Y & 3,73 \\
\hline
\end{tabular}

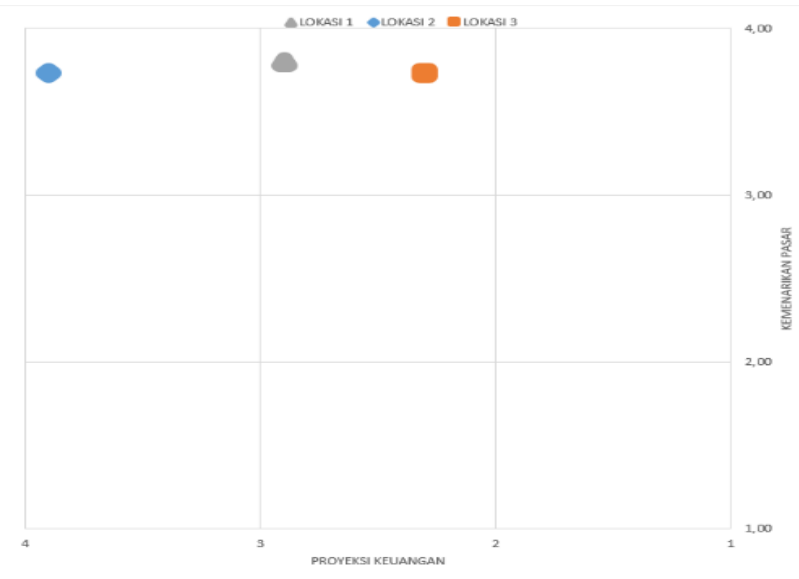

Figure 1 Office branch opening map
The results of data processing and mapping of determining business locations using GE-Matrix are as follows table 3 .

Table 3. Data Processing and Mapping of Determining Business Locations

\begin{tabular}{|l|cc|}
\hline \multicolumn{3}{|c|}{ Location 1 } \\
\hline $\begin{array}{l}\text { Segment } \\
\text { Market attractiveness score }\end{array}$ & 3,80 & 1 Opened Branch \\
Unit business power score & 2,90 & \\
\hline \multicolumn{2}{|c|}{ Location 2 } \\
\hline Market attractiveness score & 3,73 & 1 Opened Branch \\
Unit business power score & 3,90 & \\
\hline & Location 3 \\
\hline Segment & & 1 Opened Branch \\
Market attractiveness score & 3,73 & \\
Unit business power score & 2,30 & \\
\hline
\end{tabular}

\section{CONCLUSIONS}

Based on the mapping results of Location 1 (Terusan Buah Batu) in segment 1 with a recommendation to "open a shop", Location 2 (Buah Batu) in segment 1 with the recommendation to "open a shop". While location 3 (Unisba Campus) in segment 2 of the "re-projection" recommendation.

Furthermore, the results of the feasibility study using GE-Matrix mapping obtained is positive recommendations with high, based on the score, the business location chosen is eligible to be opened.

\section{ACKNOLEDGMENT}

Based on the results of data processing and mapping the determination of business locations using the BCGMatrix, the recommended locations to open are location 1 and location 2, but based on financial projections and market potential aspects, location 2 is better than location 1.

\section{REFERENCES}

[1] a. Rikalovic, I. Cosic, And D. Lazarevic, "Gis Based Multi-Criteria Analysis For Industrial Site Selection," 2014, Doi: 10.1016/J.Proeng.2014.03.090.

[2] I. Alamsyah, "Proyeksi Keuangan Menggunakan Mapping Bcg Matriks Yang Dimodifikasi Pada Usaha Kecil Menengah ( Studi Kasus Pada Usaha Kuliner ' Ayam Edward ' )," Vol. 10, No. April, 2019.

[3] C. S. Galbraith And A. F. De Noble, "Competitive Strategy And Flexible Manufacturing: New Dimensions In High-Technology Venture-Based Economic Development,” J. Bus. Ventur., 1992, Doi: 10.1016/0883-9026(92)90015-J. 
[4] F. Karakaya And C. Canel, "Underlying Dimensions Of Business Location Decisions," Ind. Manag. Data Syst., 1998, Doi: 10.1108/02635579810205395.

[5] N. Indarti, "Business Location And Success: The Case Of Internet Café Business In Indonesia," Gadjah Mada Int. J. Bus., 2004, Doi: 10.22146/Gamaijb.5543.

[6] M. E. Espeche, W. P. Maccormack, And E. R. Fraile, "Factors Affecting Growth Of An NHexadecane Degrader Acinetobacter Species Isolated From A Highly Polluted Urban River," Int. Biodeterior. Biodegrad., 1994, Doi: 10.1016/09648305(94)90037-X.

[7] R. Bhatnagar And A. S. Sohal, "Supply Chain Competitiveness: Measuring The Impact Of Location Factors, Uncertainty And Manufacturing Practices," Technovation, 2005, Doi: 10.1016/S0166-4972(03)00172-X.

[8] B. Moriset, "The New Economy In The City: Emergence And Location Factors Of InternetBased Companies In The Metropolitan Area Of Lyon, France," Urban Stud., 2003, Doi: 10.1080/0042098032000123231.

[9] A. Dixit, C. Clouse, And N. Turken, "Strategic Business Location Decisions: Importance Of Economic Factors And Place Image," Rutgers Bus. Rev., 2019.

[10]B. L. Maccarthy And W. Atthirawong, "Factors Affecting Location Decisions In International Operations - A Delphi Study," Int. J. Oper. Prod. Manag., 2003, Doi: 10.1108/01443570310481568.

[11]N. Eldin And D. Sui, “A Com-Based Spatial Decision Support System For Industrial Site Selection," J. Geogr. Inf. Decis. Anal., Vol. 7, No. 2, Pp. 72-92, 2003.

[12]A. Virlics, "Investment Decision Making And Risk," Procedia Econ. Financ., 2013, Doi: 10.1016/S2212-5671(13)00129-9.

[13] O. Roy, "Rational Choice, Itzhak Gilboa, Mit Press, 2010, Xv + 158 Pages.," Econ. Philos., 2012, Doi: $10.1017 / \mathrm{S} 0266267112000077$.

[14] A. Aziz, P. Silvia, S. -, V. Yanti, S. Jannah, And N. Purnama, "Evaluasi Kelayakan Bisnis Pada Perencanaan Usaha (Studi Kasus Kedai Kopi Robusta Di Kota Surabaya),” J. Ekon. '45, Vol. 5, No. 1, Pp. 67-77, 2018.

[15] F. R. David And F. R. David, Full-Circle Learning Mylab. 2017.
[16] J. Hunger, David Dan Thomas L. Wheelen, Manajemen Strategis, Terjemahan, Yulianto. Yogyakarta: Andi, 2009.

[17] Kasmir And Jakfar, Studi Kelayakan Bisnis, Jakarta 13220: Kencana Prenada Media Group, 2013.

[18] L. Fitri, H. Muliawan, Manajemen Strategik Dalam Organisasi, Caps, Jakarta, 2011-11-26

[19] Pearce, John A. Ii Dan Richard B. Robinson. 2013. Manajemen Strategis (Formulasi, Implementasi, Dan Pengendalian). Jakarta: Salemba Empat.

[20] R. Popy. 2013. Manajemen Strategik. 1st Ed. Edited By S. P. Santorsa. Humaniora.

[21]L. W. Thomas. Dan D. Hunger, Manajemen Strategis, Yogyakarta. Andi, 2003. 